\title{
Interleukin-8 (IL-8) Expression in the Olive Flounder (Paralichthys olivaceus) against Viral Hemorrhagic Septicemia Virus (VHSV) Challenge
}

\author{
Kyung-Hee Kim, Hyun Chul Kim, Choul-Ji Park, Jong-Won Park, Young Mee Lee, and Woo-Jin Kim \\ Genetics and Breeding Research Center, National Institute of Fisheries Science (NIFS), Geoje 53334, Korea
}

\begin{abstract}
Interleukin-8 (IL-8) is an inflammatory cytokine that plays an important role in the inflammatory response through the activation of neutrophil cells. The expression of IL- 8 was investigated in early developmental stages of the olive flounder and in tissues of 8-month-old individuals. The expression of IL-8 increased after the initiation of the immune system rather than at the early stage of development, and high expression was observed in the gills and spleen, the organs associated with immunity and metabolism. In addition, IL-8 expression after infection by viral hemorrhagic septicemia virus significantly increased in the fin, gill, muscles, and spleen. These results suggest that IL- 8 is closely related to inflammation and immune regulation in the immune response of the olive flounder and may be used as a basis for studies on the immune systems of other fish.
\end{abstract}

Key words : Olive flounder Paralichthys olivaceus, Gene expression, Interleukin-8 (IL-8), Viral hemorrhagic septicemia virus (VHSV)

\section{INTRODUCTION}

Olive flounder (Paralichthys olivaceus) is an economically important fish species in East Asia including in Korea, contributing about half of the economic value of domestic aquaculture production (KOSIS, 2018). However, the survival rate of olive flounder is seriously affected by the aging of aquafarms, natural disasters, rapid temperature changes, high density rearing, and emergence of infectious diseases (Kim et al., 2003, 2009). Especially, a viral hemorrhagic septicemia virus (VHSV) is highly pathogenic, causing severe economic losses owing to the high mortality rate of infected fish. Nevertheless, an effective therapeutic agent is not known.

Fishes infected with VHSV have enlarged kidneys and spleens, protruding eyes, and hemorrhagic fins and gills (Kim et al., 2009; Duesund et al., 2010). The disease has been reported worldwide in freshwater fishes and marine fishes. In Korea, the disease occurs between winter and spring, during the period of low water temperature, causing serious damage to the olive flounder aquaculture industry (Kim et al., 2003; OIE, 2018).

The survival of fish in the aquatic environment starting from the fry stage is strongly dependent on the innate immune system (Beck \& Habicht, 1996; Fischer et al., 2013). Interleukin-8 (IL-8; also known as CXCL8, NAF-1,

Manuscript received July 23, 2019, Received in revised form September 10, 2019, Accepted September 19,2019

${ }^{\dagger}$ Corresponding Author : Woo-Jin Kim, Genetics and Breeding Research Center, National Institute of Fisheries Science (NIFS), Geojesi 53334, Korea. Tel: +82-55-639-5818, Fax: +82-55-639-5809, E-mail: wj2464@korea.kr

This is an Open Access article distributed under the terms of the Creative Commons Attribution Non-Commercial License (http:// creative-commons.org/licenses/by-nc/3.0) which permits unrestricted non-commercial use, distribution, and reproduction in any medium, provided the original work is properly cited. 
MDNCF-1, and NAP-1) is a typical chemokine belonging to the CXC-subfamily of cytokines involved in innate immunity (Fernandez \& Lolis, 2002; Esche et al., 2005). IL-8 is a heparin-binding protein comprised of a three stranded $\beta$-sheet and an $\alpha$-helix. It is an inflammatory cytokine produced by various cells, including macrophages, when inflammation is induced, and it activates inflammatory cells by the synergistic action of NFkB, C/EBP, and AP-1 binding elements in the inflammatory reaction (Zlotnik \& Yoshie, 2012). During an acute inflammatory reaction, it also acts as a neutrophil leukocyte chemoattractant of activators, causing various diseases (Kapp et al., 1994; Taub et al., 1996; Sun et al., 2011).

In the olive flounder, the nucleotide sequence of IL-8 was described by Lee et al. (2001) and subsequently, several studies were conducted (Zhao et al., 2015; Guo et al., 2018). IL-8 has also been reported in channel catfish (Ictalurus punctatus), common carp (Cyprinus carpio), haddock (Melanogrammus aeglefinus), large yellow croakers (Larimichthys crocea), rainbow trout (Oncorhynchus mykiss) and others, but information on the immune response is limited (Laing et al., 2002; Huising et al., 2003; Chen et al., 2005; Miyar et al., 2007; Nor et al., 2008; Zhou et al., 2018; Wang et al., 2019a,b; Xiao et al., 2019). Therefore, in this study, we analyzed the expression of IL-8 at the early developmental stage and in tissues of the olive flounder in order to investigate the immune mechanisms of IL-8. We also examined its expression in various tissues after VHSV infection.

\section{MATERIALS AND METHODS}

\section{Breeding and tissue sampling}

Olive flounders used in the experiments were grown in a 3-ton flow-through tank at $19 \pm 1{ }^{\circ} \mathrm{C}$ with natural photoperiod at the Breed Research Center of the National Fisheries Research and Development Institute. To observe gene expression at different developmental stages, samples were collected until 18 days after hatching, placed in TRISolution $^{\mathrm{TM}}$ (Bio Science Technology, Daegu, Korea), and stored at $-80^{\circ} \mathrm{C}$ until RNA isolation. To analyze gene expression in different tissues, tissue samples were collected from the brain, eye, fin, gill, intestine, kidney, liver, muscle, spleen, and stomach from healthy 8-month-old olive flounders (total length approximately $30 \mathrm{~cm}$ ) and stored at $-80^{\circ} \mathrm{C}$ until testing. The stress during sampling for each group was minimized by anesthesia using 150 ppm MS-222 (Sigma-Aldrich, St. Louis, MO, USA) (Noh et al., 2017).

\section{VHSV challenge experiment}

The VHSV challenge experiment was conducted on selected olive flounders (body length of approximately 30 $\mathrm{cm}, 8$ months old) which were divided into control group and VHSV-infected group. The control group was injected with $100 \mu \mathrm{L}$ of phosphate buffered saline, and the test group was injected a VHSV suspension $\left(10^{4.8}\right.$ TCID $_{50}$ virus/fish) (Kong et al., 2009). Each group was maintained at $13^{\circ} \mathrm{C}$ in a recirculation system, without flow and feeding. Samples from the fin, gill, kidney, liver, muscle, and spleen were collected $0,3,6,12,24,48,72$, and $96 \mathrm{~h}$ after inoculation. Each sample was pooled in equal amounts and frozen in liquid nitrogen. Frozen tissues were ground using a homogenizer and subjected to RNA extraction. The stress for each group was minimized by anesthesia using $150 \mathrm{ppm}$ MS-222 (Sigma, USA) (Noh et al., 2017).

\section{Total RNA extraction and cDNA synthesis}

Total RNA was extracted from each sample using the modified protocol with TRI-Solution ${ }^{\mathrm{TM}}$ (TS200-001; Bio Science Technology, Korea). The sample (0.2 g) was homogenized with $1 \mathrm{~mL}$ of TRI-Solution and allowed to react at room temperature for $5 \mathrm{~min}$. Then, $0.2 \mathrm{~mL}$ of chloroform was added, inverted for $15 \mathrm{~s}$, and centrifuged at $13,400 \times \mathrm{g}$ and $4^{\circ} \mathrm{C}$ for $15 \mathrm{~min}$. The same volume of 
isopropyl alcohol was added to the separated supernatant, and the mixture was inverted for $15 \mathrm{~s}$ and centrifuged for $10 \mathrm{~min}$ at $13,400 \times \mathrm{g}$ and $4^{\circ} \mathrm{C}$. The supernatant was decanted, rinsed with $75 \%$ ethanol and completely air dried. The air-dried sample was dissolved in sterile distilled water and treated with DNase-I (Sigma-Aldrich, USA) to remove gDNA contamination. Total RNA was evaluated using spectrophotometry (Eon ${ }^{\mathrm{TM}}$ Microplate Spectrophotometer; BioTek, Winooski, VT, USA) by measuring the absorbance at A260/280 and A260/230, and the samples were stored at $-80^{\circ} \mathrm{C}$ until further use. The isolated RNA was converted into complementary DNA (cDNA) using the Transcriptor First Strand cDNA Synthesis Kit (Roche Ltd., Mannheim, Germany) according to the manufacturer's protocol.

\section{Assays of IL-8 gene by quantitative real-time PCR (qRT-PCR)}

Gene expression patterns of IL-8 were analyzed using quantitative real-time PCR (qRT-PCR) (Applied Biosystems 7500 Fast Real-Time PCR System; Applied Biosystems, Foster City, CA, USA). qRT-PCR was performed using $100 \mathrm{ng} / \mu \mathrm{L}$ cDNA samples in Fast SYBR Green PCR Master Mix (Thermo Fisher Scientific, Waltham, MA, USA) under the following conditions: an initial denaturation step for $20 \mathrm{~s}$ at $95^{\circ} \mathrm{C}, 40$ cycles of $3 \mathrm{~s}$ at $95^{\circ} \mathrm{C}$ and for $30 \mathrm{~s}$ at $60^{\circ} \mathrm{C}$, followed by a final dissociation stage. IL-8 and 18S rRNA primers (GenBank accession numbers AF216646.1 and EF126037.1, respectively) were used for the analysis. The nucleotide sequences of IL-8 and the housekeeping gene 18S rRNA was obtained from the GenBank database. The IL- 8 and 18S rRNA primers of the olive flounder were designed using the Primer3 program (Rozen \& Skaletsky, 2000). The primers used for the analysis were as follows: IL-8 forward (5'-GTTGTTGCTG TGATGGTGCT-3') and IL-8 reverse (5'-GCCGGTATCTT TCAGAGTGG-3'), 18S forward (5'-ATGGCCGTTCTTAG TTGGTG-3') and 18S reverse (5'-CACACGTGATCCAGT
CAGT-3'). Standardization of the total cDNA amount was performed using the $2-{ }^{\Delta \Delta \mathrm{Ct}}$ method and $18 \mathrm{~S}$ rRNA of the olive flounder as an internal standard for data normalization (Pfaffl, 2001).

\section{Statistical analysis}

All sampling was performed in three replicates to ensure the accuracy of experimental findings, and all data are expressed as mean \pm SE $(n=3)$. The software R 3.0.1 ( $R$ Development Core Team, 2013) was used for statistical analysis of the results obtained in this study. Significant differences in data values were confirmed by one-way analysis of variance (ANOVA). Significance test for gene expression in the individuals was performed using the Tukey's honestly significant difference test at $p<0.05$.

\section{RESULTS}

\section{Distribution of IL-8 at the developmental stage}

To identify the role of IL- 8 in the early developmental stage, the temporal expression was analyzed using samples from eggs to 18-day-old larvae by qRT-PCR. The data were standardized to the values obtained for egg (set to 1.0) of the olive flounder. IL-8 mRNA levels were increased on day 1 after hatching (2.4-fold) and began to decrease from day 3 (1.3-fold) (Fig. 1). Thereafter, the decrease and increase were repeated. IL-8 mRNA levels increased significantly on day 15 (7.9-fold) and reached the highest level on day 18 (16.8-fold) (Fig. 1). In conclusion, IL-8 was not expressed in the early developmental stages, but its levels increased in later stages.

\section{IL-8 gene expression in various tissues}

To localize IL-8 in various tissues from the olive flounder and identify its function, we evaluated the expression of IL-8 using qRT-PCR. Relative tissue-specific gene expression was investigated by comparing the results with the expression of IL-8 in the brain tissue (the value set to 1 ). 


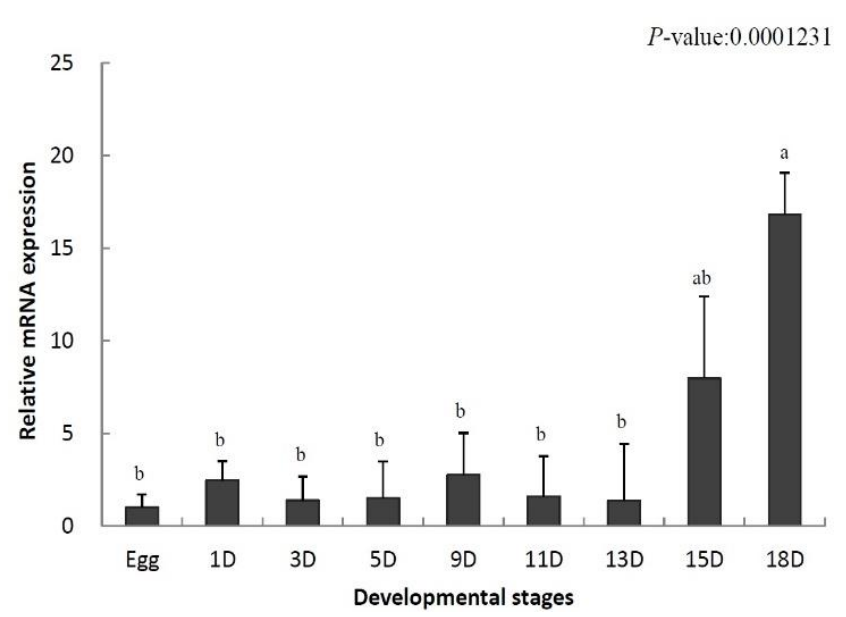

Fig. 1. Relative expression of IL-8 mRNA in different developmental stages in the whole body of the olive flounder. The mRNA expression of IL- 8 was analyzed via qRT-PCR from fertilization to 18-dayold larvae. Each experiment was performed in triplicate and the expression levels of 18S rRNA and IL-8 at the egg stage were set to 1 . IL-8, Interleukin-8.

IL-8 was increased in the fins (1.5-fold), gills (53.1-fold), intestine (12.0-fold), kidney (1.3-fold), liver (2.9-fold), muscle (5.5-fold), spleen (20.6-fold), and stomach (15.4fold) (Fig. 2). The highest gene expression of IL-8 was detected in the gill and it was relatively low in the eye. Our results show a differential expression of IL-8 in various tissues.

\section{Gene expression of IL-8 following VHSV chal-} lenge

To study the function of IL- 8 in the immune response against viral infection, we investigated the expression of the gene using qRT-PCR over a period of time in olive flounder infected with VHSV. Relative gene expression was compared with that at $0 \mathrm{~h}$, which was the starting point of the artificial infection. Overall, a similar pattern of expression was observed. The expression was slow or not significant until a specific time, but increased with time, and then decreased. The expression level in the kidney increased at $48 \mathrm{~h}$ (1.542-fold) and then decreased (Fig.

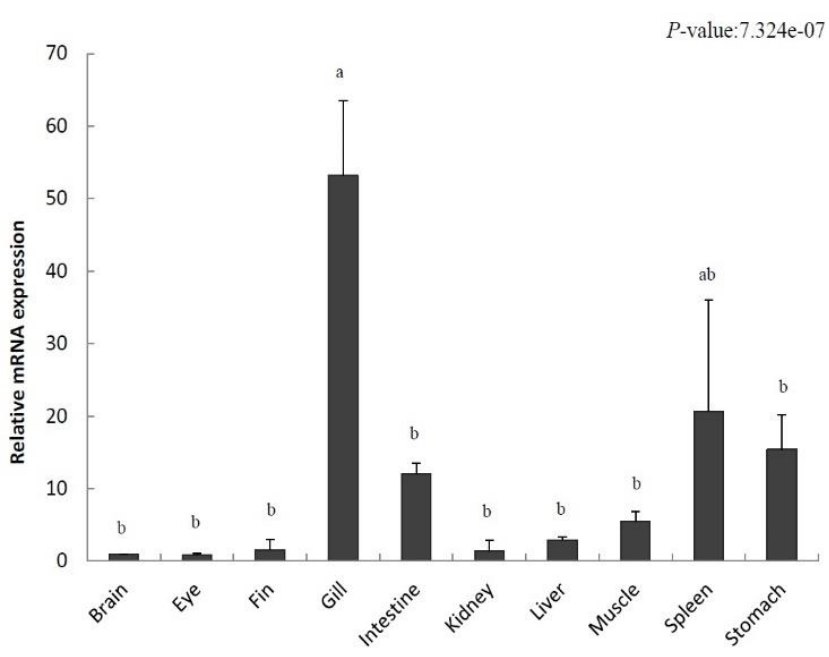

Fig. 2. Relative expression of IL-8 mRNA in various tissues of the olive flounder. IL- 8 expression in various tissues was determined via qRT-PCR. Each experiment was performed in triplicate and the expression levels of 18S rRNA and IL-8 at the egg stage were set as 1 . IL-8, Interleukin-8.

3A); IL-8 expression in the liver increased from $12 \mathrm{~h}$ (1.499-fold) to $24 \mathrm{~h}$ (2.054-fold) and then decreased (Fig. $3 \mathrm{D})$. The muscle and gill showed increasing patterns of gene expression from the beginning (Fig. 3B and E). In the muscle, IL-8 expression reached highest level at $24 \mathrm{~h}$ (41.223-fold) and then decreased rapidly (Fig. 3E). The gill also showed high expression of the gene until $12 \mathrm{~h}$ (3.472-fold), which was followed by a rapid decrease after $24 \mathrm{~h}$ (0.610-fold) (Fig. 3B). The expression levels in the fin and spleen did not show significant differences early on; the expression in the fins increased from $24 \mathrm{~h}$ (4.348fold) to $48 \mathrm{~h}$ (4.184-fold) and then decreased (Fig. 3C and F), while the expression in the spleen increased at $12 \mathrm{~h}$ (1.805-fold) and then decreased (Fig. 3C). In conclusion, the expression of IL-8 was not continuous since the time of virus inoculation, but it was expressed later and its expression decreased thereafter.

\section{DISCUSSION}

IL-8 is a small inflammatory cytokine, produced by 
A

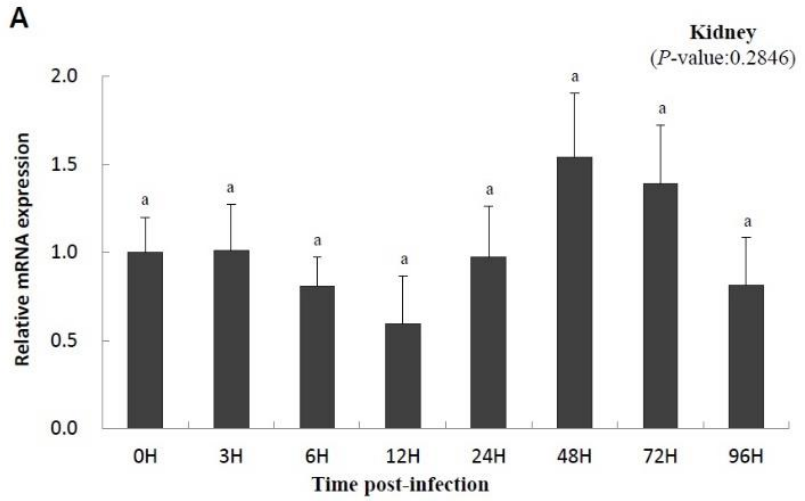

B

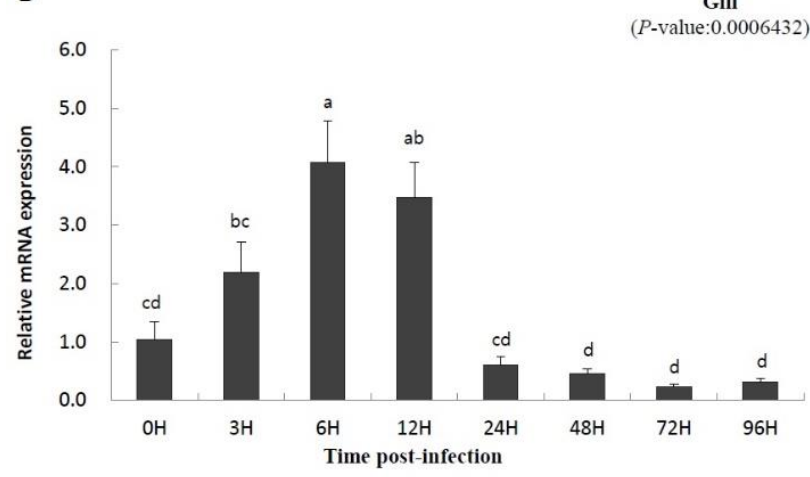

C

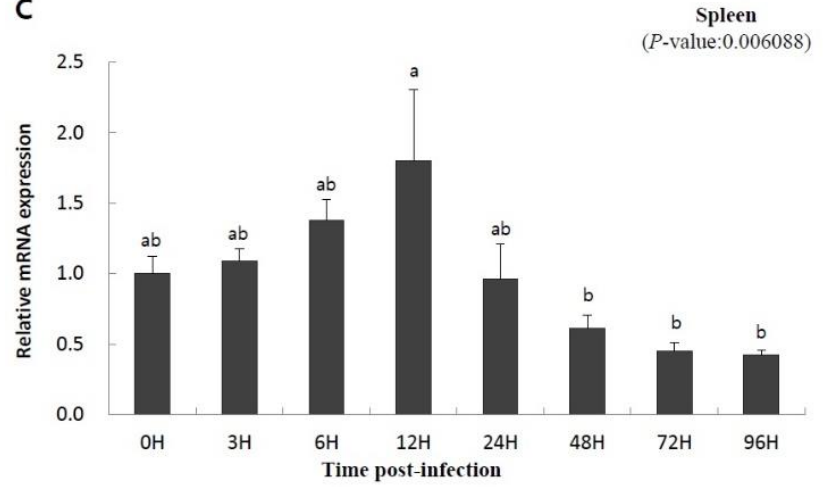

D

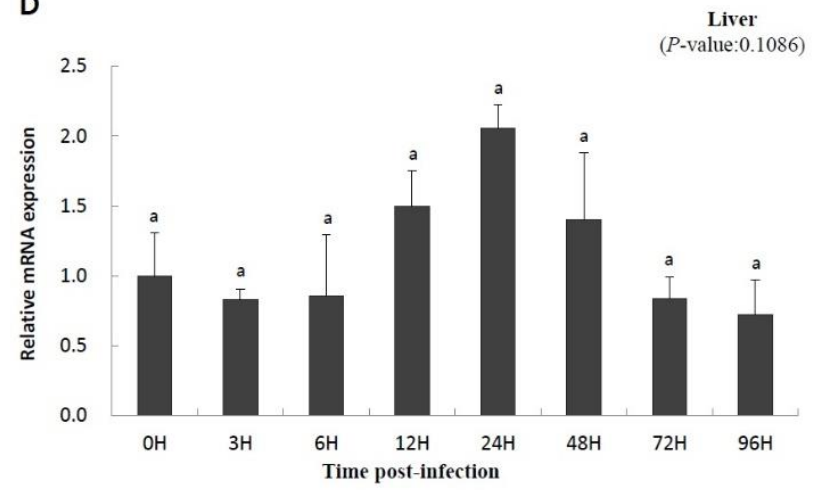

E

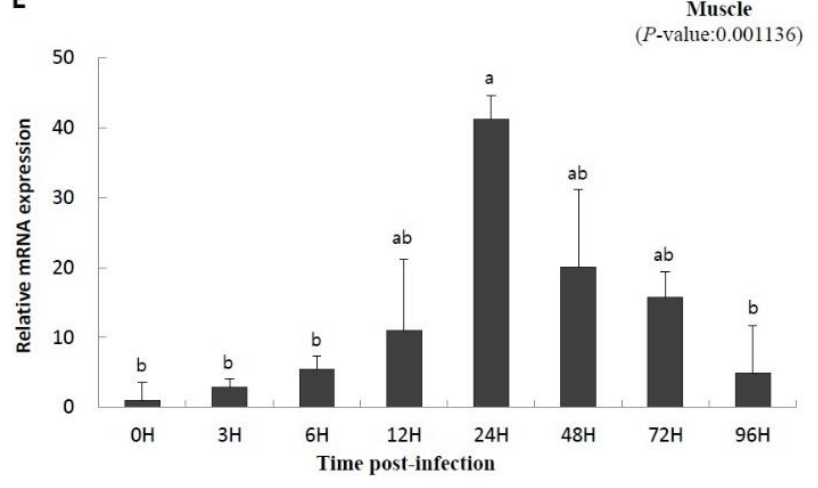

$\mathbf{F}$
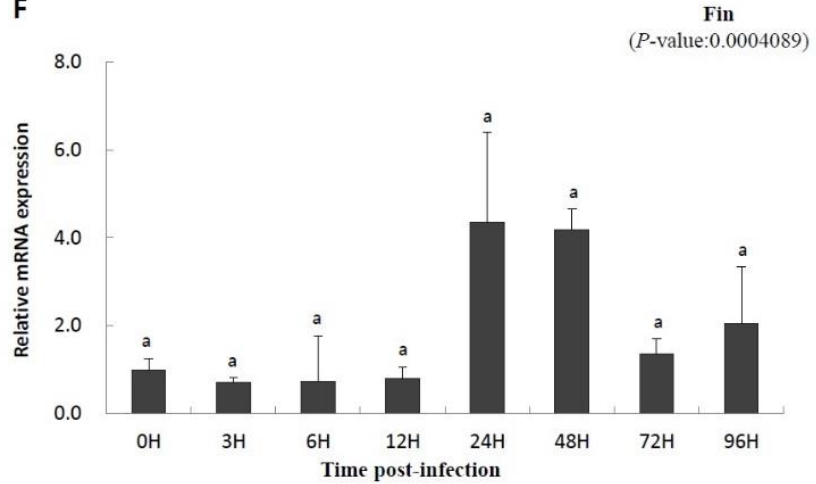

Fig. 3. Relative expression of IL-8 in the kidney (A), gill (B), spleen (C), liver (D), muscle (E), and fin (F) tissues of olive flounder within $96 \mathrm{~h}$ post- viral hemorrhagic septicemia virus (VHSV) injection. Each experiment was performed in triplicate and the expression levels of $18 \mathrm{~S}$ rRNA and IL-8 at $0 \mathrm{~h}$ were set to 1 . IL-8, Interleukin-8.

many macrophages. It acts as a secondary mediator protein in inflammatory reactions, activating inflammatory cells, and plays an important role in the inflammatory response in animals by acting as a neutrophil leukocyte chemoattractant or activator (Laing et al., 2002; Laing \& Secombes, 2004; Wang et al., 2019b). Accordingly, in this study, the properties of IL- 8 were investigated in the olive flounder infected with VHSV.
During the development of the olive flounder, the membranous fin develops immediately after hatching and the gills are formed on day 6. The digestive tract is differentiated on day 10 , and completely develops by day 14 (Kim, 2009). IL-8 was not expressed in the early developmental stages its expression increased after day 15 (Fig. 1). Based on these results, IL- 8 is not involved in the early stages of development and the fully formed immune 
system is present only in later stages of the development.

IL-8 was expressed in various tissues of the unchallenged olive flounder. In particular, its expression was the highest in gills, the respiratory organs responsible for the control of gas emission and osmotic pressure but also the most exposed organs to the aquatic environment and the route of invasion of many microorganisms (Fig. 2). This result is consistent with that found in rainbow trout, tongue sole (Cynoglossus semilaevis), and common carp (Laing et al., 2002; Mark et al., 2003; Sun et al., 2011). In addition, high IL-8 expression levels in fishes such as ayu (Plecoglossus altivelis), cobia (Rachycentron canadum), rainbow trout, and tongue sole were detected in the spleen, an important immunological organ (Laing et al., 2002; Sun et al., 2011; Chu et al., 2014; Nguyen et al., 2017). In contrast, a high expression level was observed in the liver and kidneys of the Siberian sturgeon, yellow croaker, and cobia. Our results showed that IL-8 expression occurs predominantly in immune-related organs under normal physiological conditions.

It has been reported that IL-8 expression is increased by the onset of a disease, suggesting an important role of fish IL-8 in antiviral immune response (Chu et al., 2014; Mu et al., 2015; Wang et al., 2019). In the present study, IL-8 expression was significantly increased in the fin, gill, muscle, and spleen by VHSV infection, suggesting that IL8 is involved in the immune response of the olive flounder infected with VHSV (Fig. 3B, C, E, and F). Similar to our results, induction of IL-8 in the liver, spleen, kidney, and gill by disease infection was observed in cobia, channel catfish, blue catfish, tongue sole, ayu, and the large yellow croaker (Chen et al., 2005; Tian et al., 2010; Sun et al., 2011; Chu et al., 2014; Mu et al., 2015; Nguyen et al., 2017). However, the expression of IL-8 in the kidney and liver was not significantly different between infected olive flounder individuals and the control and did not corroborate previous studies, suggesting that the expression of IL- 8 in the kidney and liver could be variably regulated in other fish species (Fig. 3A, D).

In this study, we investigated the immune response of IL-8, an inflammatory cytokine, in the activation of inflammatory cells in the olive flounder. The expression of IL-8 in a developing olive flounder was detected when the immune system of the olive flounder was formed. Its expression was high in the gills and spleen, the organs associated with immunity and metabolism. Infection with VHSV increased IL-8 expression in the fin, gill, muscle, and spleen. These results suggest that IL-8 plays an important role in the innate immune system of fish and will be useful as a basis for studying the immune response of fish.

\section{CONFLICT OF INTERESTS}

The authors declare no potential conflict of interest.

\section{ACKNOWLEDGEMENTS}

This work was supported by a grant from the National Institute of Fisheries Science (R2019001).

\section{REFERENCES}

Beck G, Habicht GS (1996) Immunity and the inverte brates. Sci Am 275:60-66.

Chen L, He C, Baoprasertkul P, Xu P, Li P, Serapion J, Waldbieser G, Wolters W, Liu Z (2005) Analysis of a catfish gene resembling interleukin-8: cDNA cloning, gene structure, and expression after infection with Edwardsiella ictaluri. Dev Comp Immunol 29:135-142.

Chu CQ, Lu XJ, Li CH, Chen J (2014) Molecular characterization of a CXCL8-like protein from ayu and its effect on chemotaxis of neutrophils and monocytes/ macrophages. Gene 548:48-55.

Corripio-Miyar Y, Bird S, Tsamopoulos K, Secombes CJ (2007) Cloning and expression analysis of two pro- 
inflammatory cytokines, IL-1 $\beta$ and IL-8, in haddock (Melanogrammus aeglefinus). Mol Immunol 44:13611373.

Duesund H, Nylund S, Watanabe K, Ottem KF, Nylund A (2010) Characterization of a VHS virus genotype III isolated from rainbow trout (Oncorhychus mykiss) at a marine site on the west coast of Norway. Virol J 7:19.

Esche C, Stellato C, Beck LA (2005) Chemokines: Key players in innate and adaptive immunity. J Invest Dermatol 125:615-628.

Fernandez EJ, Lolis E (2002) Structure, function, and inhibition of chemokines. Annu Rev Pharmacol Toxicol 42:469-499.

Fischer U, Koppang EO, Nakanishi T (2013) Teleost T and NK cell immunity. Fish Shellfish Immunol 35:197-206.

Guo M, Tang X, Sheng X, Xing J, Zhan W (2018) The effects of IL-1 $\beta$, IL- 8, G-CSF and TNF- $\alpha$ as molecular adjuvant on the immune response to an E. tarda subunit vaccine in flounder (Paralichthys olivaceus). Fish Shellfish Immunol 77:374-384.

Harun NO, Zou J, Zhang YA, Nie P, Secombes CJ (2008) The biological effects of rainbow trout (Oncorhynchus mykiss) recombinant interleukin-8. Dev Comp Immunol 32:673-681.

Huising MO, Stolte E, Flik G, Savelkoul HF, Verburg-van Kemenade BM (2003) CXC chemokines and leukocyte chemotaxis in common carp (Cyprinus carpio L.) Dev Comp Immunol 27:875-888.

Kapp A, Zeck-Kapp G, Czech W, Schopf E (1994) The chemokine RANTES is more than a chemoattractant: Characterization of its effect on human eosinophil oxidative metabolism and morphology in comparison with IL-5 and GM-CSF. J Invest Dermatol 102:906914.

Kim SM, Lee JI, Hong MJ, Park HS, Park SI (2003). Genetic relationship of the VHSV (viral hemorrhagic septicemia virus) isolated from cultured olive flounder, Paralichthys olivaceus in Korea. J Fish Pathol 16:1-12.
Kim WS, Kim SR, Kim DW, Kim JO, Park MA, Kitamura SI, Kim HY, Kim DH, Han HJ, Jung SJ, Oh MJ (2009) An outbreak of VHSV (viral hemorrhagic septicemia virus) infection in farmed olive flounder Paralichthys olivaceus in Korea. Aquaculture 296:165-168.

Kong HJ, Hong GE, Kim WJ, Kim YO, Nam BH, Lee CH, Do JW, Lee JH, Lee SJ, Kim KK (2009) Cloning and characterization of hypusine-containing protein eIF5A from the olive flounder Paralichthys olivaceus. Comp Biochem Physiol B Biochem Mol Biol 153:281-287.

Korean Statistical Information Service [KOSIS] (2018) 2018 survey on the status of Fish culture. Available at: http://kosis.kr. Accessed 23 July 2019.

Laing KJ, Secombes CJ (2004) Chemokines. Dev Comp Immunol 28:443-460.

Laing KJ, Zou JJ, Wang T, Bols N, Hirono I, Aoki T, Secombes CJ (2002) Identification and analysis of an interleukin 8-like molecule in rainbow trout Oncorhynchus mykiss. Dev Comp Immunol 26:433-444.

Lee EY, Park HH, Kim YT, Choi TJ (2001) Cloning and sequence analysis of the interleukin- 8 gene from flounder (Paralichthys olivaceous). Gene 274:237-243.

Mu Y, Wang K, Ao J, Chen X (2015) Molecular characterization and biological effects of a CXCL8 homologue in large yellow croaker (Larimichthys crocea). Fish Shellfish Immunol 44:462-470.

Nguyen TTT, Nguyen HT, Wang PC, Chen SC (2017) Identification and expression analysis of two proinflammatory cytokines, TNF- $\alpha$ and IL-8, in cobia (Rachycentron canadum L.) in response to Streptococcus dysgalactiae infection. Fish Shellfish Immunol 67:159171.

Noh GE, Kim WJ, Kim HC, Park CJ, Park JW (2017) Daily rhythms and effect of short-term starvation on the of health parameters in olive flounder Paralichthys olivaceus. Korean J Fish Aquat Sci 50:534-540.

OIE [World Organisation for Animal Health] (2018) Viral haemorrhagic septicaemia. In: Manual of Diagnostic 
Tests for Aquatic Animals. OIE, Paris, France.

Pfaffl MW (2001) A new mathematical model for relative quantification in real-time RT-PCR. Nucleic Acids Res 29:e45.

Rozen S, Skaletsky H (2000) Primer3 on the WWW for general users and for biologist programmers. In: Misener, S, Krawetz SA (ed), Bioinformatics Methods and Protocols: Methods in Molecular Biology. Humana Press, Totowa, NJ, pp 365-386.

Sun JS, Zhao L, Sun L (2011) Interleukin-8 of Cynoglossus semilaevis is a chemoattractant with immunoregulatory property. Fish Shellfish Immunol. 30:1362-1367.

Taub DD, Anver M, Oppenheim JJ, Longo DL, MurphyWJ (1996). T lymphocyte recruitment by interleukin-8 (IL8). IL-8-induced degranulation of neutrophils releases potent chemoattractants for human $\mathrm{T}$ lymphocytes both in vitro and in vivo. J Clin Invest 97:1931-1941.

Tian C, Chen Y, Ao J, Chen X (2010) Molecular characterization and bioactivity of a CXCL13 chemokine in large yellow croaker Pseudosciaena crocea. Fish Shellfish Immunol 28:445-452.

Wang T, Liang J, Xiang X, Yuan J, Chen X, Xiang X (2019a) Functional identification and expressional responses of large yellow croaker (Larimichthys crocea) interleukin- 8 and its receptor. Fish Shellfish Immunol 87:470-477.

Wang X, Ma G, Zhang R, Liu L, Zhu J, Zhu H (2019b) Molecular characterization and biological functioning of interleukin-8 in Siberian sturgeon (Acipenser baeri). Fish shellfish Immunol 90:91-101.

Xiao Y, Yu L, Gui G, Gong Y, Wen X, Xia W, Yang H, Zhang L (2019) Molecular cloning and expression analysis of interleukin- 8 and -10 in yellow catfish and in response to bacterial pathogen infection. BioMed Res Int 2019.

Zhao B, Katagiri T, Kondo H, Hirono I (2015) Comparative analysis of two types of CXCL8 from Japanese flounder (Paralichthys olivaceus). Dev Comp Immunol 52:37-47.

Zhou S, Mu Y, Ao J, Chen X (2018) Molecular characterization and functional activity of CXCL8_L3 in large yellow croaker Larimichthys crocea. Fish Shellfish Immunol 75:124-131.

Zlotnik A, Yoshie O (2012) The chemokine superfamily revisited. Immunity 36:705-716. 